\title{
Apigenin promotes apoptosis, inhibits invasion and induces cell cycle arrest of T24 human bladder cancer cells
}

Yi Zhu, Yeqing Mao, Hong Chen, Yiwei Lin, Zhenghui Hu, Jian Wu, Xin Xu, Xianglai Xu, Jie Qin and Liping Xie*

\begin{abstract}
Background: Apigenin (4,5,7-trihydroxyflavone) was recently shown effective in inhibiting several cancers. The aim of this study was to investigate the effect and mechanism of apigenin in the human bladder cancer cell line T24 for the first time.

Methods: T24 cells were treated with varying concentrations and time of apigenin. Cell viability was evaluated by MTT assay. Cell motility and invasiveness were assayed by Matrigel migration and invasion assay. Flow cytometry and western blot analysis were used to detect cell apoptosis, cell cycle and signaling pathway.

Results: The results demonstrated that apigenin suppressed proliferation and inhibited the migration and invasion potential of T24 bladder cancer cells in a dose- and time-dependent manner, which was associated with induced G2/M Phase cell cycle arrest and apoptosis. The mechanism of action is like to involve PI3K/Akt pathway and Bcl-2 family proteins. Apigenin increased caspase-3 activity and PARP cleavage, indicating that apigenin induced apoptosis in a caspase-dependent way.
\end{abstract}

Conclusions: These findings suggest that apigenin may be an effective way for treating human bladder cancer.

Keywords: Apigenin, Bladder cancer, Cell cycle arrest, Apoptosis, Invasion

\section{Background}

Apigenin, one of the most common flavonoids, is widely distributed in many fruits and vegetables, including parsley, onions, orange, tea, chamomile, wheat sprouts and in some seasonings [1]. Apigenin has potential uses in cancer prevention and therapy, and it suppresses cell growth against many human cancer cell lines, including breast, colon, skin, thyroid, leukemia, and prostate cancer cells [2-5]. Unlike other structurally related flavonoids, apigenin is non-mutagenic [6]. Although previous reports have shown the inhibitory effect of apigenin on other human cancer cells, there are few reports indicating the inhibitory effect on human bladder cancer cells.

Bladder cancer is the most common malignant tumor of the urinary tract. Worldwide, bladder cancer is the seventh most common cancer. An average of 386,300

\footnotetext{
*Correspondence: xielp@zjuem.zju.edu.cn
Department of Urology, The First Affiliated Hospital, School of Medicine,

* Correspondence: xielp@zjuem.zju.edu.cn
Department of Urology, The First Affiliated Hospital, School of Medicine,

Zhejiang University, 79 Qing Chun Road, Hangzhou, Zhejiang Province 310003, China
}

new cases of urinary bladder cancer are diagnosed worldwide every year, accounting for 150,200 deaths [7]. In recent decades, bladder cancer was shown of a rising overall incidence [8]. In most cases of nonmuscle invasive bladder cancer, tumors are treated initially with TURBT (Transurethral Resection of Bladder Tumor). A careful cystoscopic examination of the entire urethra and all bladder surfaces precedes resection. Intravesical therapy can also be employed in an expectant way as opposed to an induction course alone to provide long-term immunostimulation or chemotoxicity and thereby prevent disease recurrence $[9,10]$. Our earlier studies have shown that EGCG [11] and resveratrol [12] may be an important chemopreventive agent for the management of bladder cancer. Here we proved for the first time that apigenin could induce apoptosis and cell cycle arrest of bladder cells.

Besides many natural agents extracts like EGCG, resveratrol and genistein which are proved of the ability of cancer chemoprevention, apigenin is another agent 
we often contact. This study was designed to determine whether apigenin decreases the ability of migration and invasion of T24 bladder cells and is apoptotic of T24 bladder cells by inhibiting PI3K/Akt pathway, activating caspases and induces cell cycle arrest. Finally, we showed that in T24 bladder cancer cells apigenin upregulates Bax and Bad, activates caspase- 3 and poly (ADPribose) polymerase (PARP), inhibits PI3K/Akt pathway, downregulates antiapoptotic protein Bcl-2 and $\mathrm{Bcl}-\mathrm{x}$, and leads to G2/M cell cycle arrest.

\section{Results}

\section{Apigenin inhibits cell growth in T24 cells}

The MTT assay demonstrated that apigenin treatment with the vehicle DMSO $(1 \mathrm{ul} / \mathrm{mL})$ and varying concentrations $(10-80 \mu \mathrm{M})$ and times (24 to 72 hours), resulted in a dose- and time-dependent inhibition of T24 cell growth, compared to untreated controls. As is shown in Figure 1, there was no significant difference between untreated control and vehicle control which meant DMSO wasn't able to affect the proliferation of T24 cells. When the treated concentration was $10 \mu \mathrm{M}$, the viability of cells changed very little. Just because of this, we use the concentration of $0-20 \mu \mathrm{M}$ to complete the migration and invasion assay. With the increasing of the concentration and time, there appeared an obvious reduction in cell viability, especially with the concentration of 40 and $80 \mu \mathrm{M}$. The inhibitory concentration $50 \%$ values for apigenin treatment were estimated to be $82.5,52.9$, and $43.8 \mu \mathrm{M}$ for 24,48 , and $72 \mathrm{~h}$, respectively. These data indicated that apigenin exerts a significant inhibitory effect on T24 cells.

\section{Apigenin inhibits T24 cell migration and invasion}

As the low concentration of apigenin didn't induce a significant death of T24 cells, we treated the T24 cells with $0-20 \mu \mathrm{M}$ to detect whether the low concentration of

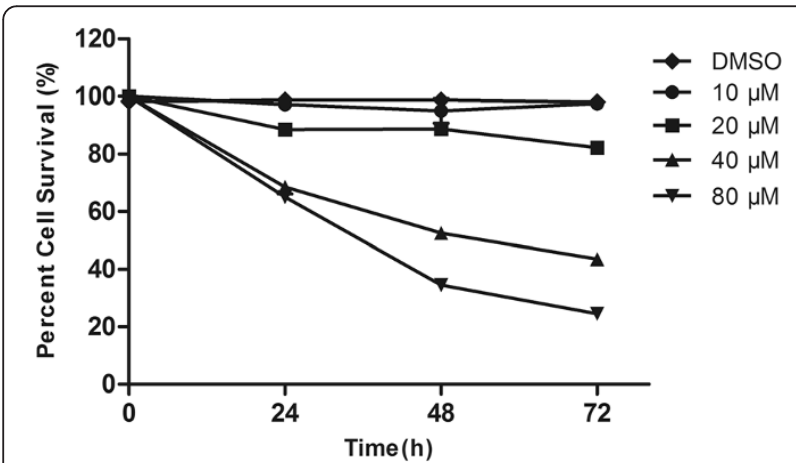

Figure 1 Cytotoxicity effects of apigenin in T24 bladder cancer cells. Cell proliferation and viability were determined by an MTT assay. Reduced cell viability with apigenin treatment $(1 \mathrm{uL} / \mathrm{mL}$ DMSO, Apigenin of 10-80 $\mu \mathrm{M}$ ) was observed at 24,48 and $72 \mathrm{~h}$. The data are presented as mean $\pm \mathrm{SD}$. apigenin decreased the migration and invasion potential of T24 cells. As shown in Figure 2, apigenin-treated cells exhibited a significant decrease in both motility and invasion compared to untreated control.

\section{Apigenin induces apoptosis in T24 cells}

To determine whether the observed apigenin-induced cell death in T24 cells occurred via induction of apoptosis, we assessed the effect of apigenin treatment on apoptosis in the next series of experiments in T24 cells. The cells were treated with varying concentration of apigenin $(0-80 \mu \mathrm{M})$ for $24 \mathrm{~h}$ and analyzed by flow cytometry. Compared with untreated control, apigenin treatment resulted in apoptosis in a dose-dependent manner (Figure $3 \mathrm{~A}$ and $\mathrm{B}$ ). The percent of apoptotic cells increased to $22.2 \%$ under the treatment of apigenin in the concentration of $80 \mu \mathrm{M}$.

Caspase- 3 activation and PARP cleavage are characteristic indicators of apoptosis. As a downstream effector in the caspase cascade, when caspase- 3 is activated, it induces an irreversible apoptosis [13]. PARP cleavage, procaspase-3 and active caspase- 3 protein were detected by western blot. In apigenin-treated T24 cell samples, cleaved PARP and active caspase-3 increased, while procaspase-3 decreased in a dose-dependent manner after $24 \mathrm{~h}$ treatment (Figure 3C).

\section{Apigenin induces G2/M phase cell cycle arrest}

Treatment of T24 cells with apigenin resulted in dose- and time-dependent inhibition of cell growth and induced apoptosis, compared with their untreated controls. We considered the possibility that this may involve an arrest of cells at specific check point in the cell cycle. We therefore assessed the effect of apigenin on cell cycle perturbations. Compared with the untreated controls, apigenin treatment leaded to an appreciable arrest of T24 cells in G2/M phase of the cell cycle. Cell cycle analysis showed that the G2/M phase population of the control cells was $14.45 \%$ and the percentage of cells in $\mathrm{G} 2 / \mathrm{M}$ phase significantly increased after $24 \mathrm{~h}$ treatment of apigenin of different concentrations. (Figure 4A) $(20.19 \%, 24.9 \%, 27.7 \%, 30.68 \%$, and $37.94 \%$ cells at 20,40,80,120, and $160 \mu \mathrm{M}$ concentrations of apigenin, respectively) after $24 \mathrm{~h}$ treatment. This increase in $\mathrm{G} 2 / \mathrm{M}$ phase cell population was accompanied with a concomitant decrease of cell number in G1 phase of the cell cycle (Figure 4B).

\section{Apigenin modulates Akt pathway}

Akt acts as an anti-apoptotic signaling molecule and is a good candidate for mediating the PI3K-dependent cell-survival responses [14]. To determine whether apigenin induces apoptosis by modulation of this pathway, we investigated the expression of total Akt and phosphorylation of Akt after treatment with apigenin of different concentrations $(0-80 \mu \mathrm{M})$ for $24 \mathrm{~h}$. Western blot analysis 


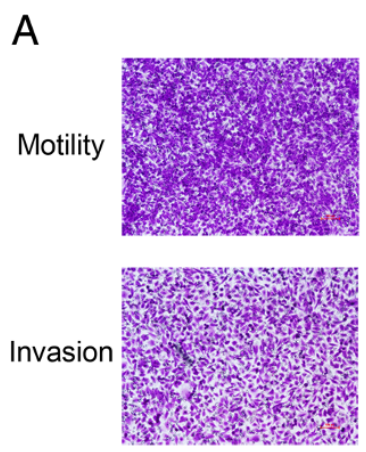

NC

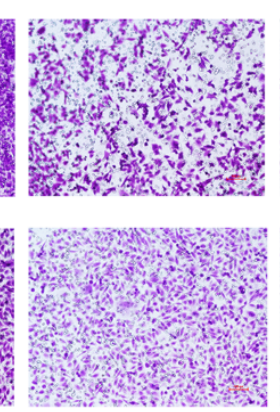

Api $(10 \mu \mathrm{M})$
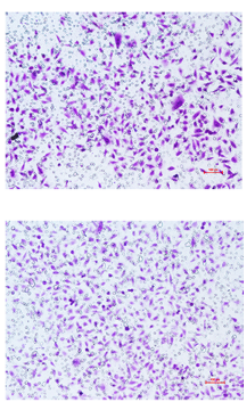

Api $(20 \mu \mathrm{M})$
B
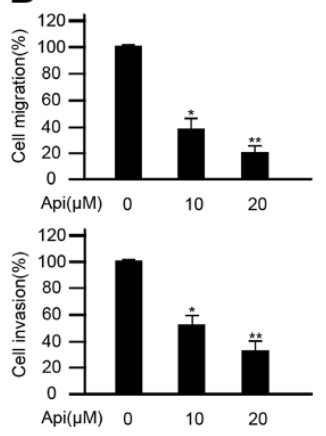

Figure 2 Effect of apigenin on T24 cell invasion and migration. Cells treated with $0-20 \mu \mathrm{M}$ apigenin were induced to move or invade through uncoated or Matrigel-coated transwell membranes. After 24 hours, cells were fixed, stained, and counted. A, a representative image; B, shows the quantitation of one experiment done in triplicate. ${ }^{*} P<0.05$ versus untreated control, ${ }^{*} P<0.01$ versus untreated control.

showed that the expression of phosphorylation of Akt (p-Akt) is decreased in a dose-dependent way, while no significant difference existed in total Akt (Figure 5A). At the same time, the protein PI3K and PDK, which phosphorylates Akt, also showed a decrease. These results indicate PI3K/Akt pathway plays an important role in the apigenin-induced apoptosis in T24 bladder cancer.

To further investigate the modulation of apigenin on PI3K-Akt pathway, T24 cells were pretreated with $20 \mu \mathrm{M}$ PI3 kinase inhibitor LY294002 for $30 \mathrm{~min}$. Cells were than treated with $40 \mu \mathrm{M}$ apigenin for another $24 \mathrm{~h}$.

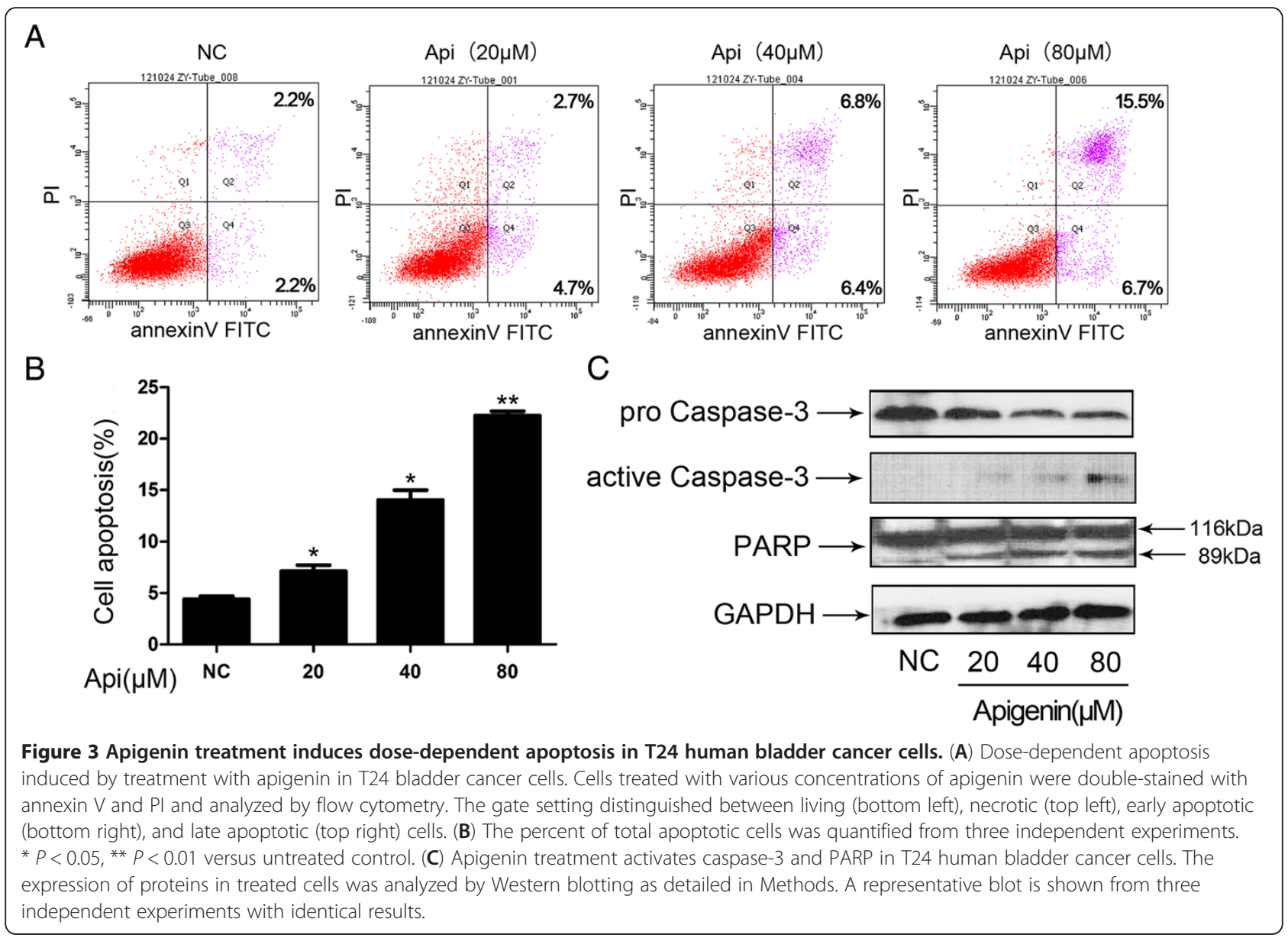




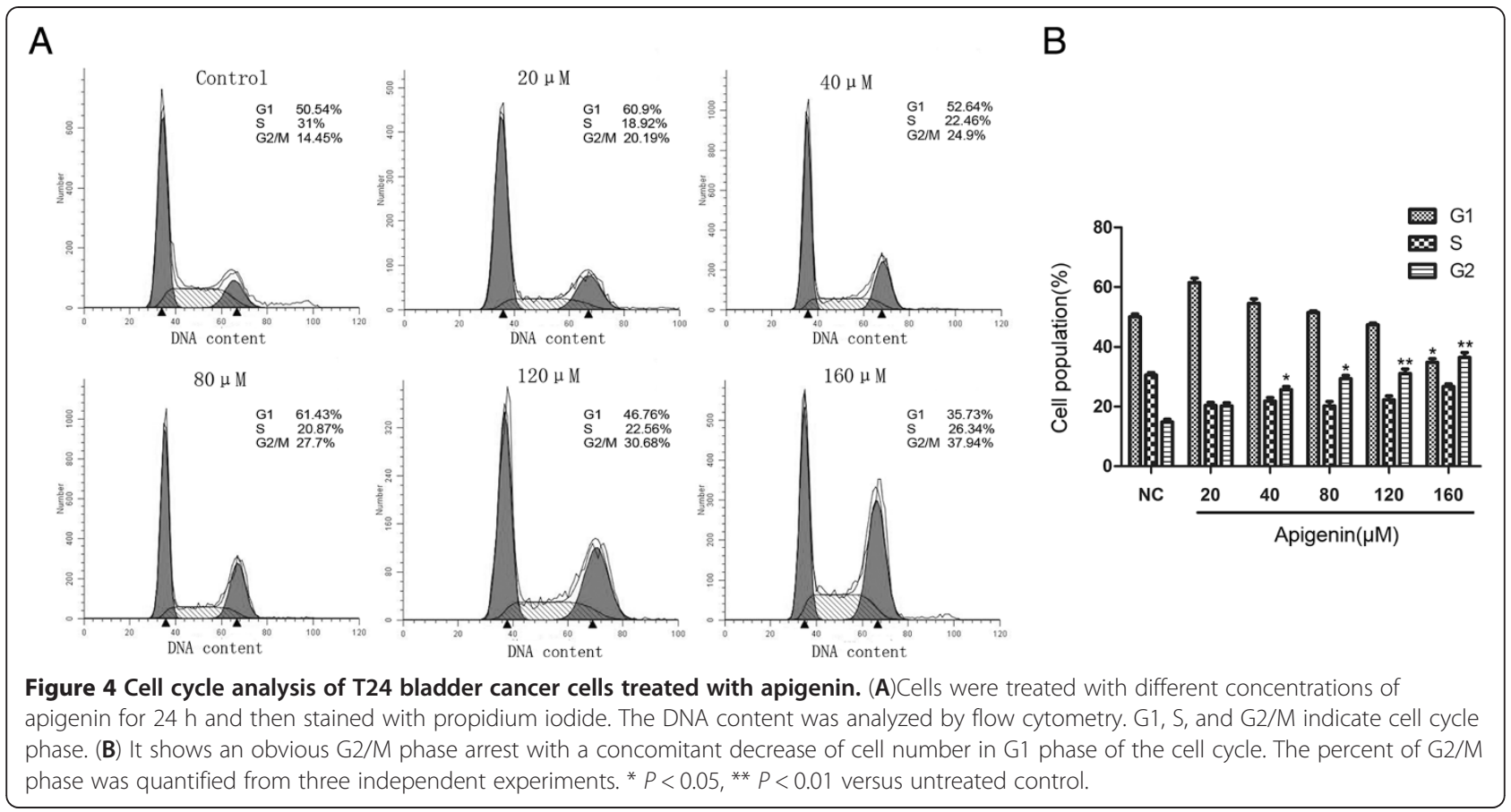

Cellular proteins were extracted and analyzed by Western blotting. As shown in Figure 5B, PI3K inhibitor, LY294002 decreased the protein levels of cleaved PARP and active casepase-3, suggesting that apigenin-induced apoptosis depended on PI3K-Akt activity.

Apigenin alters $\mathrm{Bcl}-2$ family protein expression in T24 cells As is known, Bcl-2 family plays a crucial role in apoptosis. The change of the ratio of proapoptotic protein versus antiapoptotic proteins of Bcl-2 family such as Bax and Bcl-2 will activate the mitochondrial apoptotic pathway. In addition, several kinases have been shown to phorylate and inactivate Bad, and Akt is one of them [15]. Therefore we next studied the dose-dependent effects of apigenin on the constitutive protein levels of Bcl-2 family in T24 cells. The Western blot analysis showed a significant increase in the expression of pro-apoptotic protein Bax and Bad, while in sharp contrast, the protein expression of $\mathrm{Bcl}-2$ and Bcl-xl was significantly decreased by apigenin treatment in a dose-dependent manner (Figure 5C). The results revealed evidence that apigenin-induced apoptosis was involved with Bcl-2 family.

\section{Discussion}

In this study, we showed that apigenin, a nonmutagenic antitumor flavonoid, exhibits an inhibition action on T24
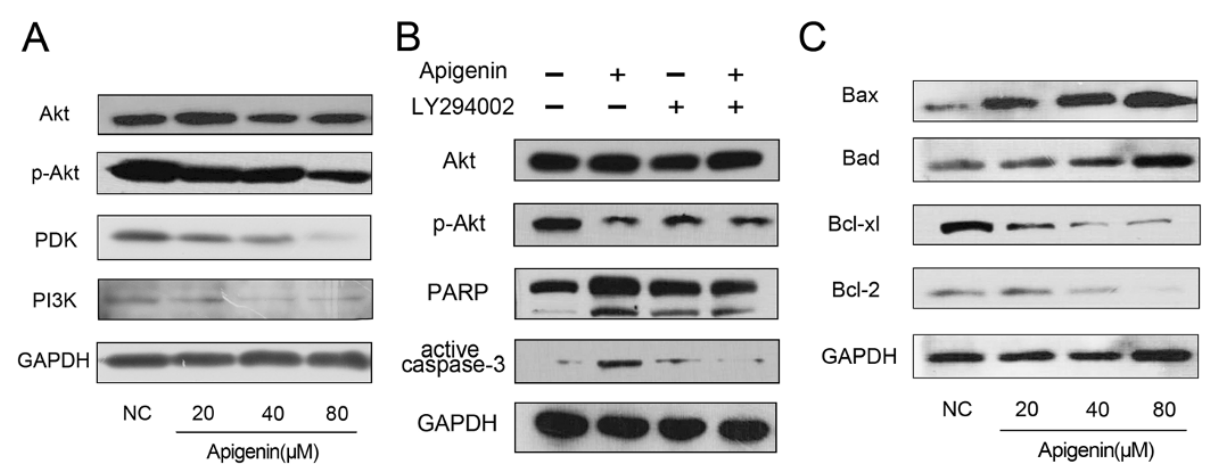

Figure 5 Expression of proteins changed in cells treated with different concentrations of apigenin or apigenin and LY294002 for $24 \mathrm{~h}$ (A) Apigenin reduced the expression phosphorylation of Akt, PI3K and PDK significantly, but the expression of total Akt had no change. (B) T24 cells was treated with $20 \mu \mathrm{M}$ PI3 kinase inhibitor LY294002 for 30 min and then with $40 \mu \mathrm{M}$ apigenin for another 24 h. Pl3K inhibitor, LY294002 decreased the protein levels of cleaved PARP and active casepase-3 which were activated by apigenin. (C) Apigenin inhibited the expression of anti-apoptotic gene products $\mathrm{BCl}-2$ and $\mathrm{BCl}-\mathrm{xL}$ but upregulated the expression of apoptotic gene product Bax and Bad. A representative blot is shown from three independent experiments with identical results. 
bladder cancer cells for the first time. We confirmed the chemopreventive/therapeutic potential of apigenin against bladder cancer by induction of apoptosis, migration and invasion inhibition and cell cycle arrest. Akt, also known as Protein Kinase B (PKB), is a serine/threonine-specific protein kinase that plays a key role in multiple cellular processes such as glucose metabolism, apoptosis, cell proliferation, transcription and cell migration. The mechanism by which Akt protects cells from death is likely to be multifactorial, because Akt directly phosphorylates several components of the cell-death machinery [16]. Some of the mechanisms involve the phosphorylation and inactivation of the apoptotic mediators Bad, caspase-9, FKHRL1, and IKK [17-23]. Besides, Akt is known to be a downstream of PI3K to regulate many biological processes. In our study, we confirmed that apigenin treatment in T24 cells induced apoptosis and inhibited the phosphorylation of Akt in a dose-dependent manner which meant the apigenin-treated apoptosis was involved with PI3K/Akt pathway. Notably, our data suggest that the mechanism of the tumor suppressive effect involved inhibition of PI3K/Akt signaling pathways. In this study, the reason why the PI3K/Akt expression level was markedly decreased by apigenin treatment is not clear. An earlier study on head and neck carcinomas suggests that apigenin targets EGFR, which is upstream of PI3K/Akt [24]. In a future study, the correlation between apigenin and EGFR expression levels in bladder cancer needs to be examined.

The Bcl-2 protein family consists of both pro-apoptotic (Bax and Bad) and anti-apoptotic (Bcl-2) proteins that regulate mitochondrial outer membrane integrity, cytochrome $c$ release, and caspase activation leading to apoptosis. Previous studies showed that with the activation of the PI3K/Akt pathway the expression of $\mathrm{Bcl}-2$ family increased [25], and Akt inhibits apoptosis through mitochondrial pathways [26]. Shifting the balance of Bcl-2 family members toward pro-apoptotic effects will activate caspase- 3 and executes the apoptotic program [27]. Therefore we investigated the effect of apigenin on Bcl-2 family. The present study indicates that apigenin treatment upregulates pro-apoptotic proteins Bax and Bad while downregulates anti-apoptotic proteins $\mathrm{Bcl}-2$ and Bcl-xl protein. Change of the Bcl-2 family induces the release of cytochrome $\mathrm{c}$ from mitochondria into cytosol and cytosolic cytochrome $\mathrm{c}$ then binds to Apaf- 1 and leads to the activation of caspase- 3 and PARP [28]. In our research, we also confirmed that apigenin activated caspase- 3 and leaded to PARP cleavage. Thus our study proved apigenin treatment induces apoptosis in T24 cells via PI3K/Akt pathway and Bcl-2 family.

Cell cycle arrest and apoptosis represent two effective mechanisms involved in the induction of cell death [29]. It is well established that loss of key cell cycle checkpoints is a hallmark of cancer cells, leading to abnormal proliferation and facilitating oncogenic transformation [30]. Observations have shown that apigenin is a potent inhibitor of cell-cycle progression in a number of different cell lines [31,32]. We also measured the effect of apigenin on cell cycle of T24 cells and found that apigenin leads to a G2/M phase arrest. The similar results were observed in human colon and breast carcinomas [4]. In the present study, G2/M phase increased from $14.45 \%$ up to $37.94 \%$, with almost 2.6 folds increasing, in a dose-dependent way, which indicated the apigenin-induced cell growth inhibition was involved with cell cycle arrest. Although Lepley $\mathrm{DM}$, et al. [32] have proved a G1 arrest by apigenin in human diploid fibroblast, we observed G2/M arrest in apigenin-treated T24 cells. The difference between these results might be attributed to the cell types tested. Previous studies have shown that PI3K/Akt pathway could regulate expression of G2/M-related proteins to influence the progression of G2 to mitosis phase. Expression of active form of Akt led to an increase in the protein and mRNA level of Cdk1, whereas Akt dominant negative mutation inhibited cell proliferation by inducing G2/M arrest [33]. Taken together, apigenin may inhibit cellular proliferation by inducing a cell cycle arrest at G2/M in T24 bladder cancer cells and probably via PI3K/Akt pathway.

\section{Conclusion}

In conclusion, our study demonstrates that apigenin can induce dose- and time-dependent cell death and apoptosis and inhibit migration and invasion ability in T24 bladder cancer cells. Apigenin leads to apoptosis via PI3K/Akt pathway, regulation of $\mathrm{Bcl}-2$ family and activation of caspase- 3 and PARP. Additionally, Apigenin also causes G2/M phase arrest. All these results indicate that apigenin can be used as a chemopreventive agent in bladder cancer. To the best of our knowledge, this is the first report showing the antitumor effect of apigenin in bladder cancer in vitro. However, further investigations of the mechanism of apigenin-treated cell inhibition are necessary.

\section{Methods}

\section{Reagents and cell culture}

Apigenin ( $\geq 99 \%$ pure) and MTT were purchased from Sigma Chemical Co. (St. Louis, MO, USA). The annexin V-FITC apoptosis detection kit was from BD Biosciences (SanJose, CA, USA). Primary antibodies to Bcl-2, Bax, Bcl-xL, pro caspase-3, active caspase-3, GAPDH and poly(ADP-ribose) polymerase (PARP), and secondary antibodies were purchased from Santa-Cruz Biotechnology, Inc. (Santa Cruz, CA). Antibodies to Akt, phosphorylated Akt, PDK, PI3K and Bad were purchased from Cell Signaling Technology (Beverly, MA). The bicinchoninic acid protein assay kit was obtained from Pierce Biotechnology (Rockford, IL). 
The human bladder cancer cell line T24 was obtained from the Shanghai Institute of Cell Biology, Chinese Academy of Sciences (Shanghai, China). The cells were cultured in RPMI-1640 medium (HyClone, Logan, UT, USA) supplemented with 10\% heat-inactivated FBS (JRH Biosciences, Lenexa, KS, USA), $100 \mathrm{U} / \mathrm{ml}$ penicillin, and $100 \mathrm{mg} / \mathrm{L}$ strep-tomycin. Cultures were maintained in a humidified atmosphere of $5 \% \mathrm{CO}_{2}$ at $37^{\circ} \mathrm{C}$.

\section{Cell viability assay}

The effect of apigenin on the viability of T24 cells was evaluated by MTT assay. Approximately $10 \times 10^{4}$ T24 cells were seeded on 96-well plates. After overnight incubation, the cells were treated with vehicle DMSO $(1 \mathrm{uL} / \mathrm{mL})$ and different concentrations of apigenin $(0-80 \mu \mathrm{M}$ in DMSO) for 24 hours. After incubation for the indicated time, MTT $(20 \mu \mathrm{L}$ of $5 \mathrm{mg} / \mathrm{mL})$ was added to each well and incubated at $37^{\circ} \mathrm{C}$ for $4 \mathrm{~h}$, after which the MTT solution in the medium was removed. To achieve solubilization of the formazan crystal formed in viable cells, $150 \mu \mathrm{L}$ DMSO was added to each well before the absorbance at $490 \mathrm{~nm}$ was measured using an MRX II absorbance reader (Dynex Technologies, Chantilly, VA, USA). Results were expressed as a percentage of growth, with 100\% representing control cells treated with DMSO alone.

\section{In vitro invasion and motility assays}

The invasion and motility assays were done as previously described [34] with some minor modifications. Cells were plated in a 6-well plate at a density of $8 \times 10^{4}$ cells/ well. After overnight incubation, cells were treated with different concentrations of apigenin (0-20 $\mu \mathrm{M}$ in DMSO) for 24 hours and harvested. The treated and the control cells were suspended in medium at a concentration of $4 \times 10^{5}$ cells $/ \mathrm{mL}$, and $0.2 \mathrm{~mL}$ of each was added to the top chamber of uncoated (for motility assays) or Matrigel-coated (for invasion assays) PET membranes (24-well insert, 8- $\mu \mathrm{m}$ pore size; Millipore, Bedford, MA). Medium $(0.6 \mathrm{~mL})$ supplemented with $20 \%$ fetal bovine serum was added to each well of the plate to act as a chemoattractant in the lower chamber. Cells were incubated for 24 hours, and those that did not migrate through the pores were removed by scraping the upper surface of the membrane with a cotton swab. Cells that had migrated to the lower surface of the membrane were fixed for $5 \mathrm{~min}$ in $100 \%$ methanol and stained with $0.1 \%$ crystal violet for $2 \mathrm{~min}$. These experiments were done in triplicate and performed a minimum of three times.

\section{Cell apoptosis assay}

The extent of apoptosis was evaluated by annexin V-FITC and flow cytometry. Cells were grown at a density of
$1 \times 10^{6}$ cells in six-well culture dishes and were treated with different concentrations of apigenin $(0-80 \mu \mathrm{M}$ in DMSO) for $24 \mathrm{~h}$. Following treatment, the cells were harvested, washed twice with pre-chilled PBS, and resuspended in $1 \times$ binding buffer at a concentration of $1 \times 10^{6}$ cells $/ \mathrm{ml}$. One hundred microliters of such solution was mixed with $5 \mu \mathrm{L}$ annexin V-FITC and $5 \mu \mathrm{L}$ propidium iodide for $15 \mathrm{~min}$, and then $400 \mu \mathrm{L} 1 \times$ binding buffer was added. Analysis was carried out using a FC500 flow cytometer with CXP software (Beckman Coulter, Fullerton, CA, USA) within $1 \mathrm{~h}$. The percentage of apoptotic cells was assessed by CXP software.

\section{Cell cycle assay}

Cells were plated in six-well culture dishes at concentrations determined to yield $60-70 \%$ confluence within $24 \mathrm{~h}$. Cells were then treated with different concentrations of apigenin $(0-160 \mu \mathrm{M}$ in DMSO). After $24 \mathrm{~h}$, cells were washed twice with PBS then centrifuged. The pellet was fixed with $70 \%$ ethanol for $1 \mathrm{~h}$ at $4^{\circ} \mathrm{C}$. The cells were washed with PBS and resuspended with propidium iodide solution $(0.05 \mathrm{mg} / \mathrm{mL})$ containing RNase, incubated at room temperature in the dark for $30 \mathrm{~min}$. DNA content was then analyzed using the FC500 flow cytometer.

\section{Western blot analysis}

Cell were harvested at $24 \mathrm{~h}$ following apigenin treatment, washed, and lysed with lysis buffer $(10 \mathrm{mmol} / \mathrm{L}$ Tris- $\mathrm{HCl}$, $0.25 \mathrm{~mol} / \mathrm{L}$ sucrose, $5 \mathrm{mmol} / \mathrm{L}$ EDTA, $50 \mathrm{mmol} / \mathrm{L} \mathrm{NaCl}$, $30 \mathrm{mmol} / \mathrm{L}$ sodium pyrophosphate, $50 \mathrm{mmol} / \mathrm{L} \mathrm{NaF}$, $1 \mathrm{mmol} / \mathrm{LNa} 3 \mathrm{VO} 4,1 \mathrm{mmol} / \mathrm{L}$ PMSF, and $2 \%$ cocktail [pH 7.5]). Protein concentration in the resulting lysate was determined using the bicinchoninic acid protein assay. Appropriate amounts of protein $(20-30 \mu \mathrm{g})$ were separated by electrophoresis in 10-12\% Tris-glycine polyacrylamide gels and transferred to nitrocellulose membranes. Membranes were blocked then incubated overnight with the appropriate primary antibody at dilutions specified by the manufacturer. They were next washed and incubated with the corresponding HRP-conjugated secondary antibody at 1:1000 dilution in Tris-buffered saline-Tween 20 (10 mM Tris-Cl [pH 7.4], $150 \mathrm{mM} \mathrm{NaCl}, 0.1 \%$ Tween-20). Bound secondary antibody was detected using an enhanced chemiluminescence system (Pierce Biotechnology).

\section{Statistical analysis}

Statistical significance was compared between various treatment groups and controls using ANOVA. Data were considered statistically significant when P-values were $<0.05$. 


\section{Authors' contributions}

YZ participated in all aspects of the experiment and the article. YM, $\mathrm{HC}$ and $Y L$ carried out the molecular studies and drafted the manuscript. XiaX, XX JW and ZH participated in the assays. JQ participated in the design of the study and performed the statistical analysis. LX conceived of the study, and participated in its design and coordination and helped to draft the manuscript. All authors read and approved the final manuscript.

\section{Acknowledgements}

We acknowledge all members of the Key Lab of Multi-Organ Transplantation of Health Ministry for their support. This work was supported by the National Key Clinical Specialty Construction Project of China, Key medical disciplines of Zhejiang province, Combination of traditional Chinese, Medicine and health development plan project of Zhejiang province (2012RCA016) and Western medicine key disciplines of Zhejiang Province (2012-XK-A23) and Medical Scientific Research Foundation of Zhejiang Province, China (2013KYB100).

Received: 17 February 2013 Accepted: 31 May 2013 Published: 1 June 2013

\section{References}

1. Birt DF, Mitchell D, Gold B, Pour P, Pinch HC: Inhibition of ultraviolet light induced skin carcinogenesis in SKH-1 mice by apigenin, a plant flavonoid. Anticancer Res 1997, 17(1A):85-91.

2. Caltagirone S, Rossi C, Poggi A, Ranelletti FO, Natali PG, Brunetti M, Aiello $\mathrm{FB}$, Piantelli M: Flavonoids apigenin and quercetin inhibit melanoma growth and metastatic potential. Int J Cancer 2000, 87(4):595-600.

3. Wang IK, Lin-Shiau SY, Lin JK: Induction of apoptosis by apigenin and related flavonoids through cytochrome $\mathrm{c}$ release and activation of caspase-9 and caspase-3 in leukaemia HL-60 cells. Eur J Cancer 1999, 35(10):1517-1525.

4. Wang W, Heideman L, Chung CS, Pelling JC, Koehler KJ, Birt DF: Cell-cycle arrest at $\mathrm{G} 2 / \mathrm{M}$ and growth inhibition by apigenin in human colon carcinoma cell lines. Mol Carcinog 2000, 28(2):102-110.

5. Yin F, Giuliano AE, Law RE, Van Herle AJ: Apigenin inhibits growth and induces $\mathrm{G} 2 / \mathrm{M}$ arrest by modulating cyclin-CDK regulators and ERK MAP kinase activation in breast carcinoma cells. Anticancer Res 2001, 21(1A):413-420

6. Czeczot H, Tudek B, Kusztelak J, Szymczyk T, Dobrowolska B, Glinkowska G, Malinowski J, Strzelecka H: Isolation and studies of the mutagenic activity in the Ames test of flavonoids naturally occurring in medical herbs. Mutat Res 1990, 240(3):209-216.

7. Jemal ABF, Center MM, Ferlay J, Ward E, Forman D: Global cancer statistics. CA Cancer J Clin 2011, 61:69-90.

8. Weir HK, Thun MJ, Hankey BF, Ries LA, Howe HL, Wingo PA, Jemal A, Ward $E$, Anderson RN, Edwards BK: Annual report to the nation on the status of cancer, 1975-2000, featuring the uses of surveillance data for cancer prevention and control. J Natl Cancer Inst 2003, 95(17):1276-1299.

9. De Boer EC, De Jong WH, Steerenberg PA, Aarden LA, Tetteroo E, De Groot ER, Van der Meijden AP, Vegt PD, Debruyne FM, Ruitenberg EJ: Induction of urinary interleukin-1 (IL-1), IL-2, IL-6, and tumour necrosis factor during intravesical immunotherapy with bacillus Calmette-Guerin in superficial bladder cancer. Cancer Immunol Immunother 1992, 34(5):306-312.

10. Lamm DL, Blumenstein BA, Crissman JD, Montie JE, Gottesman JE, Lowe BA, Sarosdy MF, Bohl RD, Grossman HB, Beck TM, et al: Maintenance bacillus Calmette-Guerin immunotherapy for recurrent TA, T1 and carcinoma in situ transitional cell carcinoma of the bladder: a randomized Southwest Oncology Group Study. J Urol 2000, 163(4):1124-1129.

11. Qin J, Xie LP, Zheng XY, Wang YB, Bai Y, Shen HF, Li LC, Dahiya R: A component of green tea, (-)-epigallocatechin-3-gallate, promotes apoptosis in T24 human bladder cancer cells via modulation of the PI3K/ Akt pathway and Bcl-2 family proteins. Biochem Biophys Res Commun 2007, 354(4):852-857.

12. Bai $Y$, Mao QQ, Qin J, Zheng XY, Wang YB, Yang K, Shen HF, Xie LP: Resveratrol induces apoptosis and cell cycle arrest of human T24 bladder cancer cells in vitro and inhibits tumor growth in vivo. Cancer Sci 2010, 101(2):488-493.

13. Boatright KM, Salvesen GS: Mechanisms of caspase activation. Curr Opin Cell Biol 2003, 15(6):725-731.
14. Franke TF, Hornik CP, Segev L, Shostak GA, Sugimoto C: PI3K/Akt and apoptosis: size matters. Oncogene 2003, 22(56):8983-8998.

15. Pugazhenthi S, Nesterova A, Sable C, Heidenreich KA, Boxer LM, Heasley LE, Reusch JE: Akt/protein kinase B up-regulates $\mathrm{Bcl}-2$ expression through cAMP-response element-binding protein. J Biol Chem 2000, 275(15):10761-10766.

16. Vivanco I, Sawyers CL: The phosphatidylinositol 3-Kinase AKT pathway in human cancer. Nat Rev Cancer 2002, 2(7):489-501.

17. Datta SR, Dudek H, Tao X, Masters S, Fu H, Gotoh Y, Greenberg ME: Akt phosphorylation of BAD couples survival signals to the cell-intrinsic death machinery. Cell 1997, 91(2):231-241.

18. Cardone MH, Roy N, Stennicke HR, Salvesen GS, Franke TF, Stanbridge E, Frisch S, Reed JC: Regulation of cell death protease caspase- 9 by phosphorylation. Science 1998, 282(5392):1318-1321.

19. Brunet A, Bonni A, Zigmond MJ, Lin MZ, Juo P, Hu LS, Anderson MJ, Arden KC, Blenis J, Greenberg ME: Akt promotes cell survival by phosphorylating and inhibiting a Forkhead transcription factor. Cell 1999, 96(6):857-868.

20. Ozes ON, Mayo LD, Gustin JA, Pfeffer SR, Pfeffer LM, Donner DB: NF-kappaB activation by tumour necrosis factor requires the Akt serine-threonine kinase. Nature 1999, 401(6748):82-85.

21. Romashkova JA, Makarov SS: NF-kappaB is a target of AKT in antiapoptotic PDGF signalling. Nature 1999, 401(6748):86-90

22. Ahmed NN, Grimes HL, Bellacosa A, Chan TO, Tsichlis PN: Transduction of interleukin-2 antiapoptotic and proliferative signals via Akt protein kinase. Proc Natl Acad Sci U S A 1997, 94(8):3627-3632.

23. Medema RH, Kops GJ, Bos JL, Burgering BM: AFX-like Forkhead transcription factors mediate cell-cycle regulation by Ras and PKB through p27kip1. Nature 2000, 404(6779):782-787.

24. Masuelli L, Marzocchella L, Quaranta A, Palumbo C, Pompa G, Izzi V, Canini A, Modesti A, Galvano F, Bei R: Apigenin induces apoptosis and impairs head and neck carcinomas EGFR/ErbB2 signaling. Front Biosci 2011, 16:1060-1068.

25. Asnaghi L, Calastretti A, Bevilacqua A, D'Agnano I, Gatti G, Canti G, Delia D, Capaccioli S, Nicolin A: Bcl-2 phosphorylation and apoptosis activated by damaged microtubules require mTOR and are regulated by Akt. Oncogene 2004, 23(34):5781-5791.

26. Chan TO, Rittenhouse SE, Tsichlis PN: AKT/PKB and other D3 phosphoinositide-regulated kinases: kinase activation by phosphoinositide-dependent phosphorylation. Annu Rev Biochem 1999, 68:965-1014.

27. Brown GC, Borutaite V: Nitric oxide, cytochrome $\mathrm{c}$ and mitochondria. Biochem Soc Symp 1999, 66:17-25.

28. Yang J, Liu X, Bhalla K, Kim CN, Ibrado AM, Cai J, Peng TI, Jones DP, Wang X: Prevention of apoptosis by $\mathrm{BCl}-2$ : release of cytochrome $\mathrm{c}$ from mitochondria blocked. Science 1997, 275(5303):1129-1132.

29. King KL, Cidlowski JA: Cell cycle regulation and apoptosis. Annu Rev Physiol 1998, 60:601-617.

30. Pan J, She M, Xu ZX, Sun L, Yeung SC: Farnesyltransferase inhibitors induce DNA damage via reactive oxygen species in human cancer cells. Cancer Res 2005, 65(9):3671-3681.

31. Lepley DM, Li B, Birt DF, Pelling JC: The chemopreventive flavonoid apigenin induces G2/M arrest in keratinocytes. Carcinogenesis 1996, 17(11):2367-2375.

32. Lepley DM, Pelling JC: Induction of p21/WAF1 and G1 cell-cycle arrest by the chemopreventive agent apigenin. Mol Carcinog 1997, 19(2):74-82.

33. Lee SRPJ, Park EK, Chung CH, Kang SS, Bang OS: Akt-induced promotion of cell-cycle progression at $\mathrm{G} 2 / \mathrm{M}$ phase involves upregulation of NF-Y binding activity in PC12 cells. $J$ Cell Physiol 2005, 205(2):270-277.

34. Albini A, Iwamoto $Y$, Kleinman HK, Martin GR, Aaronson SA, Kozlowski JM, McEwan RN: A rapid in vitro assay for quantitating the invasive potential of tumor cells. Cancer Res 1987, 47(12):3239-3245.

\section{doi:10.1186/1475-2867-13-54}

Cite this article as: Zhu et al:: Apigenin promotes apoptosis, inhibits invasion and induces cell cycle arrest of T24 human bladder cancer cells. Cancer Cell International 2013 13:54. 